\title{
Genotyping of South American clinical isolates of Pythium insidiosum based on single nucleotide polymorphism-based multiplex PCR
}

\section{Carla Weiblen ${ }^{1}$ (D) Maria Isabel de Azevedo ${ }^{4}$ (iD Lara Baccarin Ianiski ${ }^{2}$ iD Paula Cristina Stibbe ${ }^{1}$ Daniela Isabel Brayer Pereira ${ }^{5}$ (iD) Régis Adriel Zanette ${ }^{6}$ (iD Luís Antônio Sangioni ${ }^{1}$ Rodolfo Rivero $^{7}$ Janio Morais Santurio ${ }^{3}$ (D) Sônia de Avila Botton ${ }^{1,2^{*}}$ (ID)}

${ }^{1}$ Programa de Pós-graduação em Medicina Veterinária (PPGMV), Departamento de Medicina Veterinária Preventiva (DMVP), Universidade Federal de Santa Maria (UFSM), Centro de Ciências Rurais (CCR), Santa Maria, RS, Brasil.

${ }^{2}$ Programa de Pós-graduação em Ciências Farmacêuticas (PPGCF), Universidade Federal de Santa Maria (UFSM), Santa Maria, RS, Brasil. ${ }_{3}^{3}$ Departamento de Microbiologia e Parasitologia (Demip), Universidade Federal de Santa Maria (UFSM), Centro de Ciências da Saúde (CCS), Santa Maria, RS, Brasil.

${ }^{4}$ Faculdade de Medicina Veterinária, Universidade Federal de Minas Gerais (UFMG), Minas Gerais, RS, Brasil.

${ }^{5}$ Departamento de Microbiologia e Parasitologia, Instituto de Biologia (IB), Universidade Federal de Pelotas (UFPel), Pelotas, RS, Brasil. ${ }^{6}$ Programa de Pós-graduação em Ciências Biológicas: Farmacologia e Terapêutica, Universidade Federal do Rio Grande do Sul (UFRGS), Porto Alegre, RS, Brasil.

${ }^{7}$ Laboratorio Regional Noroeste DILAVE “Miguel C. Rubino”, ministério de Ganadería Agricultura e Pesca Casilla de Correo, 97105-900, Santa Maria, RS, Brasil. E-mail: sabott20@gmail.com. *Corresponding author

ABSTRACT: We aimed to genotype the South American clinical isolates of Pythium insidiosum using the single nucleotide polymorphisms (SNP) of the ribosomal DNA sequences (rDNA). Previously, an SNP-based multiplex-PCR was able to distinguish three different clades of $P$. insidiosum isolates. Thus, we used this assay to evaluate South American clinical isolates of P. insidiosum ( $n=32)$, standard strains from Costa Rica ( $n=4)$, Thailand ( $n=3)$, Japan $(n=1)$, and India $(n=1)$, a standard strain of Pythium aphanidermatum, and Brazilian environmental isolates of Pythium torulosum, Pythium rhizo-oryzae and Pythium pachycaule voucher $(n=3)$. It was possible to allocate each American P. insidiosum isolate to clade I, the isolates of India, Japan, and Thailand to clade II, and the Thai isolate to clade III. P. aphanidermatum, P.torulosum, P.rhizo-oryzae and P.pachycaule voucher isolates were not amplified. For the first time, a P. insidiosum isolate from Uruguay South America, was included in molecular analyzes. By SNP-based multiplex-PCR, it was possible to perform the identification and genotyping of the South American isolates of P. insidiosum, demonstrating similar genetic characteristics of these isolates. Key words: Pythium insidiosum, Pythiosis, molecular detection, genotype, single nucleotide polimorphisms.

Genotipagem de isolados clínicos de Pythium insidiosum da América do Sul utilizando polimorfismos de nucleotídeo único baseado em PCR multiplex

RESUMO: $O$ objetivo deste estudo foi genotipar isolados clínicos de Pythium insidiosum da América do Sul utilizando polimorfismos de nucleotídeo único (SNP) de sequencias de rDNA. Anteriormente, um multiplex-PCR baseado em SNP foi capaz de distinguir P. insidiosum em três diferentes clados. Dessa forma, utilizamos este método para avaliar isolados clinicos de P. insidiosum da América do Sul (n=32), cepas padrão da Costa Rica (n=4), Tailândia $(n=3)$, Japão $(n=1)$ e Índia $(n=1)$, uma cepa padrão de Pythium aphanidermatum e isolados ambientais brasileiros de Pythium torulosum; Pythium rhizo-oryzae e Pythium pachycaule voucher ( $n=3)$. Os isolados analisados foram alocados aos clados: I (americanos), II (isolados da Índia, Japão e Tailândia), e III (um isolado tailandês). P. aphanidermatum, P.torulosum, P.rhizo-oryzae e P.pachycaule voucher não foram amplificados. Pela primeira vez, um isolado de P. insidiosum do Uruguai foi incluído em análises moleculares. Através da multiplex-PCR baseada em SNP, foi possivel realizar a identificação e genotipagem dos isolados sulamericanos de P. insidiosum, demonstrando características genéticas semelhantes entre esses isolados.

Palavras-chave: Pythium insidiosum, Pitiose, detecção molecular, genótipo, polimorfismos de nucleotídeo único.

\section{INTRODUCTION}

Pythium genus is an ecofriendly oomycete found in a varied ecosystem. Most species are saprobic or pathogens of plants, algae, fishes, insects, and mammals (ADHIKARI et al.,
2013). Pythium insidiosum causes pythiosis, a relevant infectious disease in human and animals that is widely distributed throughout the world (GAASTRA et al., 2010). In Brazil, this oomycete is present predominantly in the swampy areas of Pantanal Mato-Grossense and Rio Grande do Sul 
State (RS) (SANTOS et al., 2014; WEIBLEN et al., 2016). Little is known about the presence of pythiosis in some countries of South America, such as Uruguay, where the first case in an equine was recently reported in Costas del Tacuarí, Departamento de Treinta y Tres (LABORATORIO REGIONAL ESTE DE DILAVE, 2012).

Due to the difficulty of diagnosing pythiosis and the high costs for laboratory identification of $P$. insidiosum, as well as the similarity to other agents, especially other oomycetes and filamentous fungi, there is a need for diagnostic tools that can identify rapidly this relevant microorganism. VILELA et al. (2015) proposed a biochemical assay for identification of oomycetes; however, this technique should still be used carefully for the evaluation of $P$. insidiosum isolates (KRAJAEJUN et al., 2018).

Molecular biology tools have been successfully employed for diagnosing pythiosis, mainly using polymerase chain reaction (PCR) targeting the $P$. insidiosum internal transcribed spacer (ITS) of the rRNA locus, i.e., the ribosomal DNA (rDNA region) that consists of $18 \mathrm{~S}$ rRNA, internal transcribed spacer 1 (ITS1), 5.8S rRNA, internal transcribed spacer 2 (ITS2), and 28S rRNA (GROOTERS \& GEE, 2002). Phylogenetic studies of $P$. insidiosum have already been used with different genetic markers to elucidate aspects related to epidemiology, pathogenesis, and hosts (SCHURKO et al., 2003a,b; KAMMARNJESADAKUL et al., 2011; AZEVEDO et al., 2012; RIBEIRO et al., 2017). The first phylogenetic analyses grouped $P$. insidiosum in three clusters: cluster I North, Central, and South America; cluster II Australia, North America, Southeast Asia, and Thailand; and cluster III North America and isolates from Thailand (SCHURKO et al., 2003a,b). However, these analyses have limitations owing to the high costs, time required for DNA sequencing, and the delay in obtaining results.

Simple sequence repeat (SSR) and single nucleotide polymorphism (SNP) markers have been used for studies of diversity and relationship in different microorganisms, including $P$. insidiosum (SUPABANDHU et al., 2007; RUJIRAWAT et al., 2017). The purpose of our study was genotyping American clinical isolates of $P$. insidiosum using a fast, simple, and low-cost tool based on SNP multiplex PCR.

\section{MATERIALS AND METHODS}

Thirty-one clinical isolates of $P$. insidiosum from Brazil, one from Uruguay, standard strains from
Costa Rica $(n=4)$, Thailand $(n=3)$, Japan $(n=1)$, and India $(\mathrm{n}=1)$ were analyzed (Table1). Additionally, one standard strain of Pythium aphanidermatum and three environmental species of Pythium (P.torulosum, P.rhizooryzae and P.pachycaule voucher) were included in this research. All isolates were cultivated and submitted to total DNA extraction and amplification of rDNA region were according to AZEVEDO et al. (2012) using the primers ITS1 (5'-TCCGTAGGTGAACCTGCGG-3') and ITS4 (5'-CTTCCGTCAATTCCTTTAAG-3') (WHITE et al., 1990). The primers used for SNP multiplex PCR amplification were ITS1, R1 (5'-CCTCACATTCTGCCATCTCG-3'), R2 (5'-ATACCGCCAATAGAGGTCAT-3'), and R3 (5'-TTACCCGAAGGCGTCAAAGA-3') (RUJIRAWAT et al., 2017). Amplifications were performed according to RUJIRAWAT et al. (2017) with modifications. Briefly, in a final volume of $25 \mu \mathrm{L}$, the PCR reaction contained $1 \mu \mathrm{M}$ of the forward primer ITS1, $0.5 \mu \mathrm{M}$ each of the reverse primers (R1, R2, and R3), 1.5 units of Taq DNA polymerase (Invitrogen), $200 \mu \mathrm{M}$ of each deoxynucleotide, $1.5 \mathrm{mM} \mathrm{MgCl}_{2}$, $1 \mathrm{x}$ enzyme buffer, and 100ng of DNA sample. The amplifications were carried out in a programmable thermal cycler (PTC-100, MJ Research), with initial denaturation at $95^{\circ} \mathrm{C}$ for $5 \mathrm{~min}, 20$ cycles of denaturation at $95^{\circ} \mathrm{C}$ for $30 \mathrm{~s}$, annealing at $53^{\circ} \mathrm{C}$ for $30 \mathrm{~s}$, and extension at $72^{\circ} \mathrm{C}$ for $45 \mathrm{~s}$, and then a final extension at $72^{\circ} \mathrm{C}$ for $10 \mathrm{~min}$. A $5 \mu \mathrm{L}$ aliquot of the PCR product was submitted to electrophoresis on $1 \%$ agarose gels, stained with ethidium bromide, and visualized under ultraviolet light.

The PCR products of rDNA region presenting a single band with the desired length (approximately 500-800pb) were purified with PureLink PCR Purification Kit (Invitrogen), and the DNA was sequenced in an automatic sequencer (ABIPrism 3500 Genetic Analyzer) using the primers ITS1 and ITS4 (WHITE, 1990). Phylogenetic analysis for rDNA region was conducted by Neighbor-joining (NJ) method with 10,000 bootstrap replicates. All rDNA sequences from $P$. insidiosum clinical isolates from South America and standard strains of Costa Rica, India, Japan and Thailand, as well as P. aphanidermatum, P.torulosum, P.rhizo-oryzae and P.pachycaule voucher and Phytopythium vexans (outgroup) were used to construct the phylogenetic tree.

\section{RESULTS AND DISCUSSION}

Based on the multiplex PCR targeting the three SNPs identified in the rDNA region, all the thirty-six South and Central American isolates of $P$. insidiosum and the five standard strains from 
Thailand, India and Japan were grouped in their respective clades, as suggested by RUJIRAWAT et al. (2017) (Table 1, Figure 1). We observed that the American clinical isolates, grouped in clade I, generated amplicons of approximately 490 and $660 \mathrm{bp}$ when using the primers ITS1/R1 and ITS1/R2, respectively. P. aphanidermatum, P.torulosum, P.rhizo-oryzae and P.pachycaule voucher were not amplified since these isolates do not belong to any P. insidiosum clade.

The multiplex PCR targeting the three SNPs identified in the rDNA region was developed by RUJIRAWAT et al. (2017) and has many advantages, such as $100 \%$ of sensitivity, and specificity, rapid and cost-effective identification, and genotyping of $P$. insidiosum. As these authors evaluated only one Brazilian isolate of $P$. insidiosum in their study, we proposed to evaluate an expressive number of $P$. insidiosum clinical isolates from South America using this technique.

The molecular phylogeny obtained for the rDNA region showed $P$. insidiosum as paraphyletic in relation to other Pythium species. However, it was observed that South and Central American $P$. insidiosum isolates were grouped together, forming a monophyletic group. In addition, isolates from other countries formed a basal-positioning group in relation to the American isolates (Figure 2). These results were consistent with AZEVEDO et al. (2012) and RIBEIRO et al (2017) that used
rDNA (ITS) and cytochrome c oxidase subunit II as molecular markers and exo-1,3- $\beta$ glucanase gene in phylogenetic analyses of Brazilian $P$. insidiosum isolates, respectively. Moreover, all isolates of $P$. insidiosum from India, Japan and Thailand were grouped in different clades as proposed by SCHURKO et al. (2003 a,b) and lately supported by SUPABANDHU et al. (2008).

According to RUJIRAWAT et al. (2017) multiplex PCR targeting the three SNPs identified in the rDNA (ITS) region were able to allocate $P$. insidiosum to clade-I provided two amplicons (approximately 490 and 660bp), whereas the cladesII and -III showed only one amplicon (approximately 660 and $800 \mathrm{bp}$, respectively). The same results were obtained in this study, allowing to assign each American $P$. insidiosum isolates to clade I, isolates from India, Japan, and Thailand to clade II, and one Thai isolate to clade III. In addition, $P$. aphanidermatum, P.torulosum, P.rhizo-oryzae and P.pachycaule voucher were not amplified. Thus, these results evidenced that this molecular biology methodology is specific and sensitive for identification and genotyping of $P$. insidiosum, in agreement with RUJIRAWAT et al. (2017).

The genome sequences of $P$. insidiosum recently available can be a useful genetic resource for exploring aspects related the biology and evolution

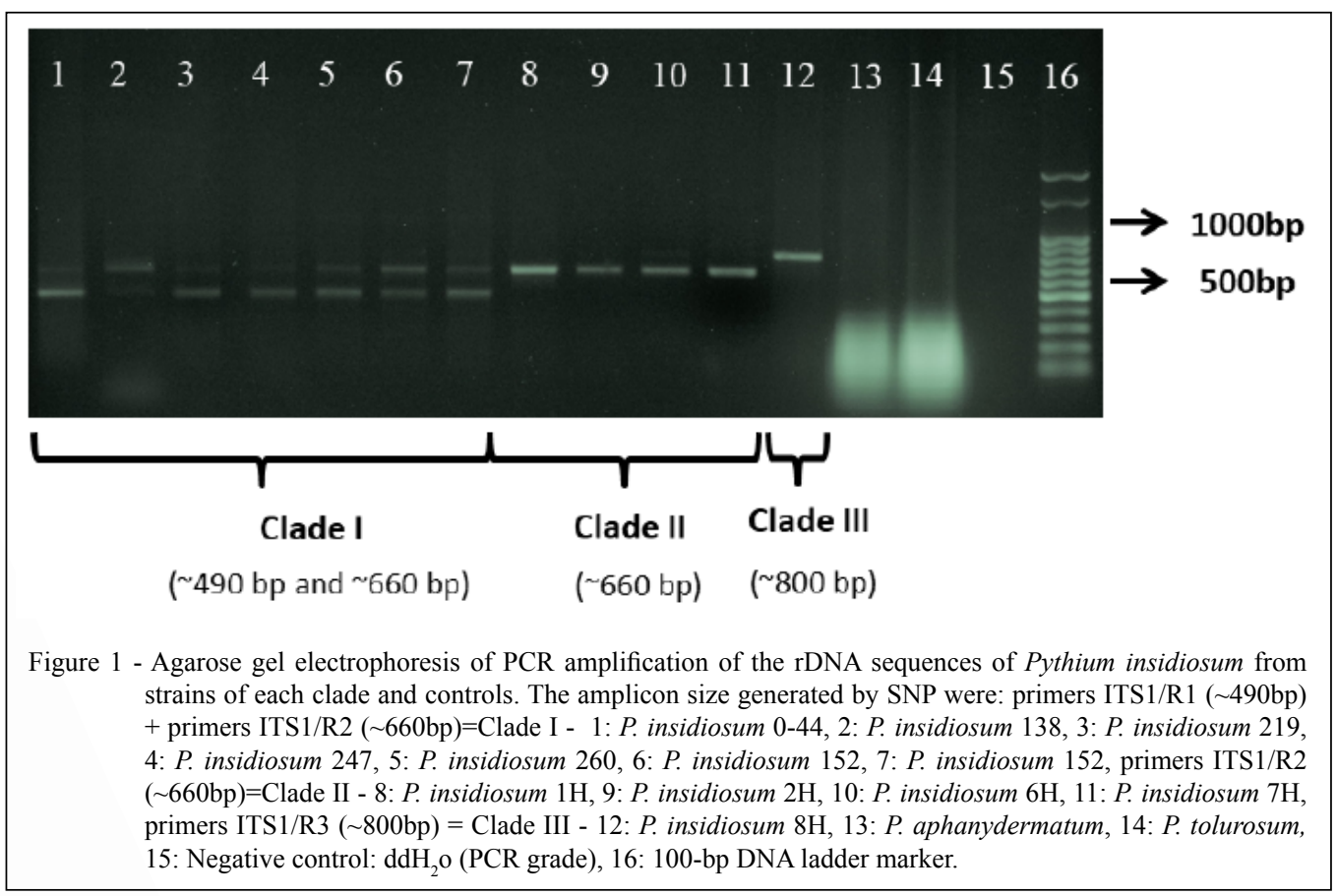

Ciência Rural, v.49, n.1, 2019. 
Table 1 - Isolates of Pythium. insidiosum $(\mathrm{n}=36)$ and other species of Pythium $(\mathrm{n}=4)$ used for evaluation of the multiplex PCR assay and their information of GenBank acession number of rDNA sequence, isolate source, geographic origin and phylogenetic clade.

\begin{tabular}{|c|c|c|c|c|c|}
\hline Isolate & GenBank $^{\#}$ & Isolate source & Geographic origin & Amplicon (bp) & Clade \\
\hline $0-44$ & MF767408 & Equine & Uruguay & $\sim 490$ and $660 \mathrm{pb}$ & I \\
\hline 118 & JN126280 & Equine & Jaguari $^{*}$ & $\sim 490$ and $660 \mathrm{pb}$ & I \\
\hline 121 & JN126282 & Equine & Santa Maria ${ }^{*}$ & $\sim 490$ and $660 \mathrm{pb}$ & I \\
\hline 123 & JN126283 & Equine & Cachoeira do Sul ${ }^{*}$ & $\sim 490$ and $660 \mathrm{pb}$ & I \\
\hline 126 & JN126286 & Equine & Corumbá ${ }^{*}$ & $\sim 490$ and $660 \mathrm{pb}$ & I \\
\hline 135 & MH813295 & Equine & Corumbá* & $\sim 490$ and $660 \mathrm{pb}$ & I \\
\hline 137 & MH813296 & Equine & Corumbá* & $\sim 490$ and $660 \mathrm{pb}$ & I \\
\hline 138 & JN126289 & Equine & Corumbá* $^{*}$ & $\sim 490$ and $660 \mathrm{pb}$ & I \\
\hline 142 & MH813297 & Equine & Corumbá* & $\sim 490$ and $660 \mathrm{pb}$ & I \\
\hline 143 & JN126290 & Equine & Corumbá* & $\sim 490$ and $660 \mathrm{pb}$ & I \\
\hline 152 & MH813298 & Equine & Santa Maria ${ }^{*}$ & $\sim 490$ and $660 \mathrm{pb}$ & I \\
\hline 156 & JN126293 & Equine & Santa Maria ${ }^{*}$ & $\sim 490$ and $660 \mathrm{pb}$ & I \\
\hline 178 & JN126295 & Equine & Corumbá & $\sim 490$ and $660 \mathrm{pb}$ & I \\
\hline 187 & JN126296 & Equine & Jari ${ }^{*}$ & $\sim 490$ and $660 \mathrm{pb}$ & I \\
\hline 210 & JN126298 & Equine & Uruguaiana* $^{*}$ & $\sim 490$ and $660 \mathrm{pb}$ & I \\
\hline 219 & JN126299 & Equine & São Lourenço do Sul ${ }^{*}$ & $\sim 490$ and $660 \mathrm{pb}$ & I \\
\hline 223 & JN126300 & Equine & Cachoeira do Sul ${ }^{*}$ & $\sim 490$ and $660 \mathrm{pb}$ & I \\
\hline 232 & JN126302 & Equine & Uruguaiana* $^{*}$ & $\sim 490$ and $660 \mathrm{pb}$ & I \\
\hline 247 & JN126304 & Equine & Restinga Seca ${ }^{*}$ & $\sim 490$ and $660 \mathrm{pb}$ & I \\
\hline 252 & MH813299 & Equine & Uruguaiana* $^{*}$ & $\sim 490$ and $660 \mathrm{pb}$ & I \\
\hline 254 & MH813300 & Equine & Pelotas ${ }^{*}$ & $\sim 490$ and $660 \mathrm{pb}$ & I \\
\hline 259 & JN126306 & Equine & Santa Vitória do Palmar* & $\sim 490$ and $660 \mathrm{pb}$ & I \\
\hline 260 & JN126307 & Equine & Santa Vitória do Palmar ${ }^{*}$ & $\sim 490$ and $660 \mathrm{pb}$ & I \\
\hline 268 & JX675977 & Canine & Canguçu $^{*}$ & $\sim 490$ and $660 \mathrm{pb}$ & I \\
\hline 271 & MH813301 & Equine & Silveira Martins ${ }^{*}$ & $\sim 490$ and $660 \mathrm{pb}$ & I \\
\hline 290 & KJ176713 & Equine & Santa Maria ${ }^{*}$ & $\sim 490$ and $660 \mathrm{pb}$ & I \\
\hline 291 & MH813302 & Equine & Pelotas* & $\sim 490$ and $660 \mathrm{pb}$ & I \\
\hline 293 & MH813303 & Equine & Rio Grande ${ }^{*}$ & $\sim 490$ and $660 \mathrm{pb}$ & I \\
\hline 295 & MH813304 & Canine & Pelotas* & $\sim 490$ and $660 \mathrm{pb}$ & I \\
\hline 296 & MH813305 & Equine & Pelotas ${ }^{*}$ & $\sim 490$ and $660 \mathrm{pb}$ & I \\
\hline 337 & MH813306 & Equine & Jaguari* $^{*}$ & $\sim 490$ and $660 \mathrm{pb}$ & I \\
\hline 339 & MH813307 & Equine & Uruguaiana & $\sim 490$ and $660 \mathrm{pb}$ & I \\
\hline ATCC 58637 & JN126310 & Equine & Costa Rica & $\sim 490$ and $660 \mathrm{pb}$ & I \\
\hline CBS 57485 & AY598637 & Equine & Costa Rica & $\sim 490$ and $660 \mathrm{pb}$ & I \\
\hline 3H - CBS 57685 & AB898106 & Equine & Costa Rica & $\sim 490$ and $660 \mathrm{pb}$ & I \\
\hline 4H- CBS 57585 & AB971178 & Equine & Costa Rica & $\sim 490$ and $660 \mathrm{pb}$ & I \\
\hline 1H-CBS 119453 & EF016853 & Human & Thailand & $\sim 660$ & II \\
\hline 2H-CBS 119455 & EF016855 & Human & Thailand & $\sim 660$ & II \\
\hline 6H- CBS 70283 & AY 151170 & Equine & Japan & $\sim 660$ & II \\
\hline 7H- CBS 77784 & AY151169 & Mosquito larva & India & $\sim 660$ & II \\
\hline 8H- CBS 119454 & AB971185 & Human & Thailand & $\sim 800$ & III \\
\hline P.aphanidermatum CBS 128995 & JF412451 & Human & Afghanistan & NA & - \\
\hline P.torulosum & MH813308 & Environmental & Capão do Leão* & NA & - \\
\hline P.rhizo-oryzae & MH813309 & Environmental & Santa Vitória do Palmar ${ }^{*}$ & NA & - \\
\hline P.pachycaule voucher & MH813310 & Environmental & Santa Vitória do Palmar ${ }^{*}$ & NA & - \\
\hline
\end{tabular}

${ }^{\#}$ GenBank acession number corresponding to rDNA (ITS) sequences. ${ }^{\#}$ Amplicon size generated by SNP (base pair) using: Primers ITS1/R1 ( 490 bp) + Primers ITS1/R2 ( 660bp) $=$ Clade I; Primers ITS1/R2 $(\sim 660 \mathrm{bp})=$ Clade II; Primers ITS1/R3 $(\sim 800 \mathrm{bp})=$ Clade III; and no amplification $)=$ No $P$. insidiosum genotype. $=$ This isolate does not belong to $P$. insidiosum clade. ${ }^{*}$ Municipality of Brazil. 


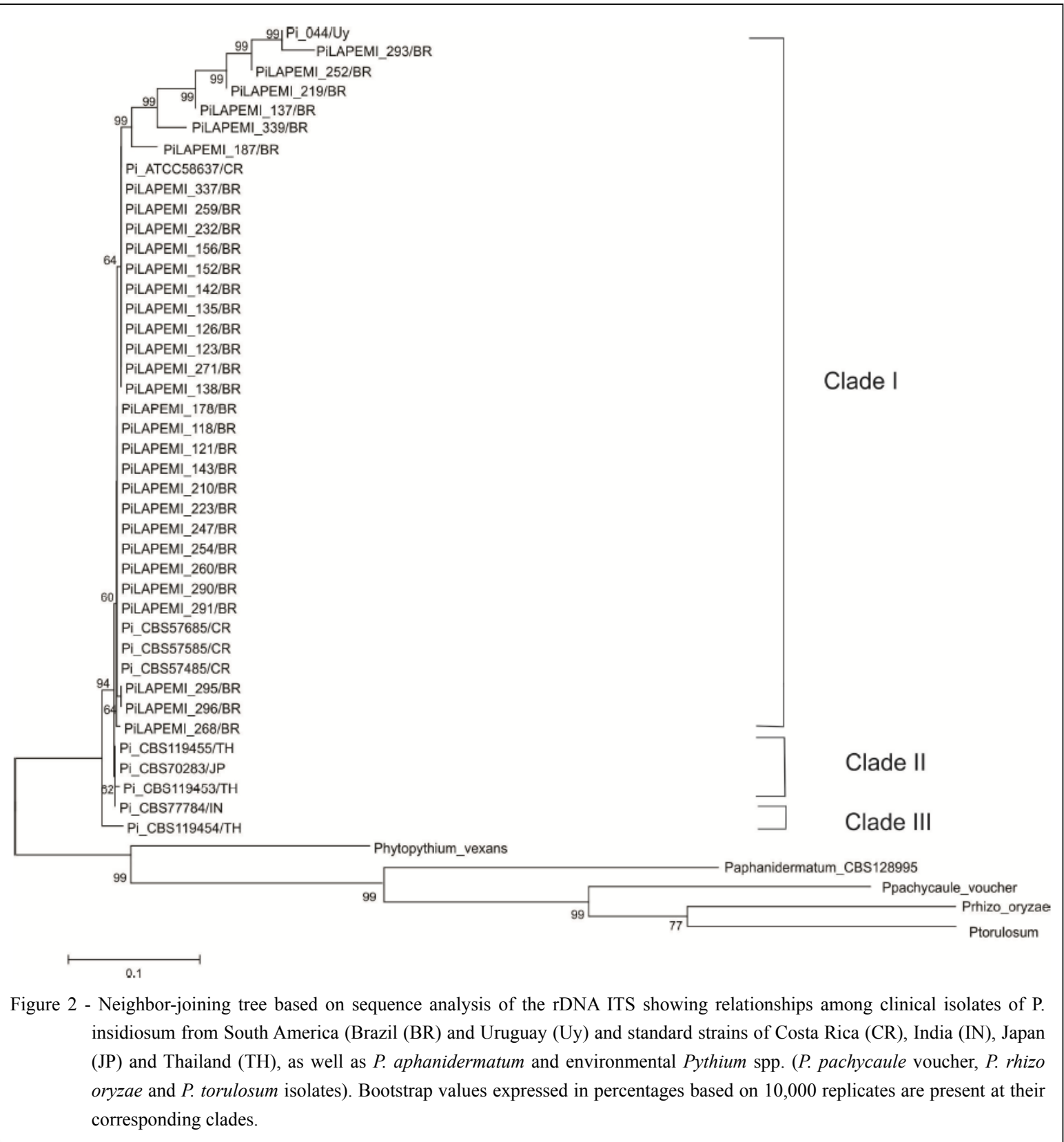

P.insidiosum and other oomycetes since independently assessed genes may not provide much information when compared to genomes. However, genome analyses are still recent, expensive and laborious when compared to the available molecular analyses (RUJIRAWAT et al., 2015; TANGPHATSORNRUANGA et al., 2016).

For the first time, a $P$. insidiosum isolate from Uruguay were included in phylogenetic analysis.
A single case of equine pythiosis has been reported by the Laboratorio Regional Este de DILAVE (2012). It is of note there is still little knowledge about pythiosis in Uruguay. However, we are aware of other cases of equine pythiosis in that country (unpublished data). Additionally, MACHADO et al. (2018) suggested that $P$. insidiosum is a generalist pathogen that has the potential to move between the borders of southern Brazil, e.g., RS (the southernmost state in Brazil)

Ciência Rural, v.49, n.1, 2019. 
and Uruguay. $P$. insidiosum isolate from Uruguay was grouped in clade I, together with isolates from Brazil. This was evidenced by both multiplex PCR and phylogenetic analysis, proving that the South American isolates are grouped in the same clade, as previously suggested (SCHURKO et al., 2003a,b; KAMMARNJESADAKUL et al., 2011; AZEVEDO et al., 2012; RIBEIRO et al., 2017).

\section{CONCLUSION}

The SNP-based multiplex-PCR methodology has benefits (i.e., fast, simple, and lowcost) and was possible to carry out the identification and genotyping of the South American isolates of $P$. insidiosum. For the first time a $P$. insidiosum isolate from equine in Uruguay was identified and genotyped. Furthermore, the American $P$. insidiosum isolates evaluated showed similar genetic characteristics.

\section{ACKNOWLEDGMENTS}

The authors are grateful to Conselho Nacional de Desenvolvimento Científico e Tecnológico (CNPq: 442020/2014-7), Fundação de Amparo à Pesquisa do Estado do Rio Grande do Sul (PqG/FAPERGS: 27293.414.15435.20062017) and Coordenação de Aperfeiçoamento de Pessoal de Nível Superior (CAPES) (finance code 001) for scientific, financial support and student's scholarships.

\section{DECLARATION OF CONFLICTING INTERESTS}

The authors declare no conflict of interest. The founding sponsors had no role in the design of the study; in the collection, analyses, or interpretation of data; in the writing of the manuscript, and in the decision to publish the results.

\section{AUTHORS' CONTRIBUTIONS}

The authors contributed equally to the manuscript.

\section{REFERENCES}

ADHIKARI, B.N. et al. Comparative genomics reveals insight into virulence strategies of plant pathogenic oomycetes. Plos One, v.8, n.10, e75072, 2013. Available from: <https://journals.plos.org/ plosone/article?id=10.1371/journal.pone.0075072>. Accessed: Jul. 10, 2018. doi: 10.1371/journal.pone.0075072.

AZEVEDO, M.I. et al. Phylogenetic relationships of Brazilian isolates of Pythium insidiosum based on ITS rDNA and cytochrome oxidase II gene sequences. Veterinary Microbiology, v.159, n.12, p.141-148, 2012. Available from: <https://www.ncbi.nlm.nih. gov/pubmed/22483240>. Accessed: Jul. 10, 2018. doi: 10.1016/j. vetmic.2012.03.030.

GAASTRA, W. et al. Pythium insidiosum: an overview. Veterinary Microbiology, v.146, n.1-2, p.1-16, 2010. Available from: <https:// www.ncbi.nlm.nih.gov/pubmed/20800978>. Accessed: Jul. 10, 2018. doi: 10.1016/j.vetmic.2010.07.019.

GROOTERS, AM.; GEE, MK. Development of a nested polymerase chain reaction assay for the detection and identification of Pythium insidiosum. Journal of Veterinary Internal Medicine, v.16, n.2, p.147-152, 2002. Available from: <https://www.ncbi. nlm.nih.gov/pubmed/11899029>. Accessed: Jul. 10, 2018.

KRAJAEJUN, T. Biochemical and genetic analyses of the oomycete Pythium insidiosum provide new insights into clinical identification and urease-based evolution of metabolism-related traits. PeerJ, v.6, e4821, 2018. Available from: <https://www.ncbi. nlm.nih.gov/pubmed/29888122>. Accessed: Oct. 29, 2018. doi: $10.7717 /$ peerj. 4821

KAMMARNJESADAKUL, P. Phylogenetic analysis of Pythium insidiosum. Thai strains using cytochrome oxidase II (COX II) DNA coding sequences and internal transcribed spacer regions (ITS). Medical Mycology, v.49, n.3, p.289-295, 2011. Available from: $<$ https://www.ncbi.nlm.nih.gov/pubmed/20818919>. Accessed: Oct. 29, 2018. doi: 10.3109/13693786.2010.511282

LABORATORIO REGIONALESTE DE DILAVE. Pitiosis equina. Archivo Veterinario del Este, v.4, n., p.12-14, 2012. Available from: $\quad<$ https://www.researchgate.net/publication/274699691 Archivo Veterinario del Este - 1213 2012>. Accessed: Jul. 10, 2018. doi: $10.13140 / \mathrm{rg} .2 .1 .3010 . \overline{7} 682$.

MACHADO, G. et al. Potential distribution of Pythium insidiosum in Rio Grande do Sul, Brazil, and projections to neighbour countries. Transboundary and Emerging Diseases, p.1-9, 2018. Available from: <https://www.ncbi.nlm.nih.gov/pubmed/29920968>. Accessed: Jul. 10, 2018. doi: 10.1111/tbed.12925.

RIBEIRO, T.C. et al. Microevolutionary analyses of Pythium insidiosum isolates of Brazil and Thailand based on exo-1,3$\beta$-glucanase gene. Infection, Genetics and Evolution, v.48, n.58-63, 2017. Available from: <https://www.ncbi.nlm.nih.gov/ pubmed/27894990>. Accessed: Jul. 10, 2018. doi: 10.1016/j. meegid.2016.11.020.

RUJIRAWAT, T. et al. Draft genome sequence of the pathogenic oomycete Pythium insidiosum strain $\mathrm{Pi}-\mathrm{S}$, isolated from a patient with pythiosis. Genome Announcements, v.3, n.3, e00574-15, 2015. Available from: <https://www.ncbi.nlm.nih. gov/pmc/articles/PMC4472884/>. Jul. 10, 2018. doi: 10.1128/ genomeA.00574-15.

RUJIRAWAT, T. et al. Single nucleotide polymorphismbased multiplex PCR for identification and genotyping of the oomycete Pythium insidiosum from humans, animals and the environment. Infection, Genetics and Evolution. v.54, p.429436, 2017. Available from: <https://www.ncbi.nlm.nih.gov/ pubmed/28826756>. Accessed: Jul. 10, 2018. doi: 10.1016/j. meegid.2017.08.004.

SANTOS, C.E.P. et al. Epidemiological survey of equine pythiosis in the Brazilian pantanal and nearby areas: results of 76 cases. Journal of Equine Veterinary Science, v.34, p.270-274, 2014. Available from: <https://www.sciencedirect.com/science/article/ pii/S0737080613004152>. Accessed: Jul. 10, 2018. doi: 10.1016/j. jevs.2013.

SCHURKO, A.M. et al. A molecular phylogeny of Pythium insidiosum. Mycology Research, v.107, n.5, p.537-544, 2003a. 
SCHURKO, A. et al. Evidence for geographic clusters: Molecular genetic differences among strains of Pythium insidiosum from Asia, Australia and the Americas are explored. Mycologia, v.95, n.2, p.200-208, 2003b.

SUPABANDHU, J. et al. Polymorphic microsatellite markers for the human oomycete pathogen Pythium insidiosum. Molecular Ecology Resources, v.7, n.6, p.1088-1090, 2007 Available from: $<$ https://onlinelibrary.wiley.com/doi/abs/10.1 111/j.1471-8286.2007.01787.x>. Accessed: Jul. 10, 2018. doi: 10.1111/j.1471-8286.2007.01787.x.

SUPABANDHU, J. et al. Isolation and identification of the human pathogen Pythium insidiosum from environmental samples collected in Thai agricultural areas. Medical Mycology, v.46, n.1, p.41-52, 2008. Available from: <https://www.ncbi. nlm.nih.gov/pubmed/17885956>. Accessed: Jul. 10, 2018. doi: $10.1080 / 13693780701513840$

TANGPHATSORNRUANGA, S. et al. Comparative mitochondrial genome analysis of Pythium insidiosum and related oomycete species provides new insights into genetic variation and phylogenetic relationships. Gene, v.575, n.1, p.34-41, 2016. Available from: <https://www.sciencedirect.com/science/article/ pii/S0378111915010057?via\%3Dihub>. Accessed: Oct. 29, 2018 doi: 10.1016/j.gene.2015.08.036.

VILELA, R. et al. A biochemical screening approach to putatively differentiate mammalian pathogenic oomycota species in the clinical laboratory. Journal of Medical Microbiology, v.64, p.862-868, 2015. Available from: <https://www.ncbi.nlm.nih. gov/pubmed/26293112>. Accessed: Jul. 10, 2018. doi: 10.1099/ jmm.0.000111.

WEIBLEN, C. et al . Seroprevalence of Pythium insidiosum infection in equine in Rio Grande do Sul, Brazil. Ciência Rural, v.46, n.1, p.126-131, 2016. Available from: <http://www.scielo.br/ scielo.php?script=sci_arttext\&pid=S0103-84782016000100126>. Jul. 10, 2018. doi: 10.1590/0103-8478cr20150056.

WHITE, T. Amplification and direct sequencing of fungal ribosomal RNA genes for phylogenetics. In: Innis, M., Gelfand, D., Sninsky, J.J. (Eds.), PCR Protocols: A Guide to Methods and Applications. Academic Press, New York, 1990, 315-322. 